\title{
WHY DESIST HYPHENATED IDENTITIES? READING SYED AMANUDDIN'S DON'T CALL ME INDO-ANGLIAN
}

\author{
Susheel Kumar Sharma \\ sksharma@allduniv.ac.in \\ University of Allahabad, India
}

Received November 12, 2018; Revised November 22, 2018; Accepted December 24, 2018

\begin{abstract}
The paper analyses Syed Amanuddin's “Don't Call Me Indo-Anglian” from the perspective of a cultural materialist. In an effort to understand Amanuddin's contempt for the term, the matrix of identity, language and cultural ideology has been explored. The politics of the representation of the self and the other that creates a chasm among human beings has also been discussed. The impact of the British colonialism on the language and psyche of people has been taken into account. This is best visible in the seemingly innocent introduction of English in India as medium of instruction which has subsequently brought in a new kind of sensibility and culture unknown hitherto in India. Indians experienced them in the form of snobbery, racism, highbrow and religious bigotry. P C Ray and M K Gandhi resisted the introduction of English as the medium of instruction. However, a new class of Indo-Anglians has emerged after independence which is not different from the Anglo-Indians in their attitude towards India. The question of identity has become important for an Indian irrespective of the spatial or time location of a person.
\end{abstract}

Keywords: hyphenated identity, hybridity, culture, English, Indo-Anglian, Syed Amanuddin

Шарма Сушіл Кумар. Навіщо потрібно відмовитися від розщепленої ідентичності? Інтерпретація твору «Не називай мене індо-англійцем» Седа Амануддина.

Анотація. У статті проаналізовано твір Седа Амануддина «Не називай мене індоанглійцем» 3 перспективи культурного матеріаліста. Із метою розуміння зневаги Амануддина до згаданого терміна, досліджено матрицю ідентичності, мовну та культурну ідеологію. Також обговорюється питання політики щодо уявлення себе та іншого, що призводить до утворення прірви між людьми. Береться до уваги вплив битанського колоніал ізму на мову та психіку людей. Його ознаки добре простежуються в на перший погляд невинному запровадженні англійської в Індії як мови навчання, що з часом породило новий, раніше невідомий в Індії, вид чуттєвості та культури. Для індійців це втілилося у формі снобізму, расизму, інтелектуального та релігійного фанатизму. П С Рей та М К Ганді чинили опір запровадженню англійської як мови викладання. Водночас після здобуття незалежності в Індії з'явився новий клас індо-англійців, що загалом не відрізнявся від англо-індійців у своєму ставленні до країни. Відтак, питання ідентичності постало для індійців досить серйозно, незалежно від просторових чи часових параметрів проживання особи.

Ключові слова: розщеплена ідентичність, гібридність, англійська мова, індо-англієць, Сед Амануддин.

\section{Introduction}

The term Indo-Anglian is a legitimate and widely used term that has also found its entry into The Oxford English Dictionary (Vol. VII) ${ }^{1}$ and The New Shorter Oxford English Dictionary on Historical Principles (Vol. I) ${ }^{2}$ so it is quite baffling to note Syed Amanuddin's ${ }^{3}$ disapprobation in using the appellation as a term of

(C) Sharma, Susheel Kumar, 2018. This is an Open Access article distributed under the terms and conditions of the Creative Commons Attribution 4.0 International Licence (http://creativecommons.org/licenses/by/4.0).

East European Journal of Psycholinguistics, 5(2), 92-107. https://doi.org/10.5281/zenodo.2583631 
description in his poem "Don't call me Indo-Anglian"4. He has enlisted the following reasons for his abomination: "a hotchpotch of culture", "a confusion of language", "a nullity of imagination", "an abortive affair between an indo and an anglo", "hate hyphens", "the artificial bridges/ between artificial values/ in the name of race religion $n$ language/i damn all hyphenated minds/ prejudiced offsprings of unenlightened souls". Let us examine the validity of reasons enumerated by him one by one.

\section{The Study}

Syed Amanuddin himself had hinted at various causes for his contempt of the term. They have been discussed point wise to see their validity. The data for the study is not only Amanuddin's poem but the entire historical, sociological, political, cultural and educational milieu has been explored to understand the context of the term in the text in the manner of a New Historicist.

\section{1. "A hotchpotch of culture"}

Culture is a cover term for everything that makes up a person's way of life. It is characterised by the following elements: social organization (families, religious groups, social classes, political and economic interest groups, friends etc), customs and traditions, rules of behaviour (both written and unwritten), symbols, language, arts and literature, ethical values, beliefs and assumptions. As it shapes one's ideas to view the reality ethnocentrism and racism are two important parameters to understand one's cultural identity. Literature is one of the keys to unlock the riddles of the culture of a social group, race and country. A large number of Indians have chosen to write in English though it is not their language. The history of this literature is almost two hundred years old. This literature has been known by various names, one being Indo-Anglian Literature.

The term 'Indo-Anglian' is used both as a noun and an adjective. While in the former case it means literature produced by or about India in English in the latter case it means related to/by Indians through English. The term "Indo-Anglian Literature" is a compound noun/phrase with the structure of Mod (Adj) + N (e.g. Black Board, Common Room, Old Boy etc) or N + N (e.g. Alphabet Worksheets, Christmas Activities etc). In contrast, in compound words like "English Literature" or "Hindi Literature" (with word structure of $\mathrm{N}+\mathrm{N}$, for example, water tank, birth place etc), Hindi or Kannada or Sindhi, the first free morpheme, refers to the language in which the literature has been produced unlike the case with 'IndoAnglian Literature' where-in the compound morpheme 'Indo-Anglian' is not the name of a language. In the title of Amanuddin's "Don't call me Indo-Anglian" the term can be interpreted as a noun as well as an adjective.

V K Gokak asserts that the term 'Indo-Anglian' "has been coined as a kind of cousin for 'Anglo-Indian'." (Gokak, n.d.: 160) Most of the scholars, some AngloIndians and the Websites maintained by the Anglo-Indians hold that the AngloIndians were brought into being by the direct policies of the Portuguese, Dutch, and British traders and colonists. Therefore, the Anglo-Indians may be correctly described as "a hotchpotch of culture"; let us look into their history to find some 
clue to understand Amanuddin's detestation. After seizing Goa from the Sultan of Bijapur in 1510, Afonso de Albuquerque, the Governor of the Portuguese State of India (Estado Português da Índia), in order to stabilize his empire started encouraging his bachelor soldiers (soldados) to become married settlers (casados) by taking Indian mistresses. Unlike the later European colonisers he neither had any notion of racial purity nor a horror of mixed marriages. Under his policy Politica dos Casamentos, Albuquerque, encouraged marriages between Portuguese men "originally from lowest classes in Portugal including some convicted criminals" (Rocha, 2010: 38) and native women as the number of Portuguese females who came with Portuguese officials (renois), those who were born to Portuguese parents in India (castiças), others who came on ships (aventureiras) and women of mixed blood (both mestiços and mulatas) in 16th century was very limited. Stephens writes: "Officers indeed might expect to return to the fatherland, but the Europeans of inferior ranks were too valuable to be allowed to escape. In all it is narrated that about 450 Portuguese were married to native women before [Albuquerque] left Goa for Malacca" (Stephens 1897: 153) As Albuquerque was very conscious of the skincolour he advised his men to marry fair Hindu and Muslim women and encouraged them to avoid dark complexioned Malabaris. (Bethencourt, 2013:210, Pearson, 1987:101) M N Pearson writes further: "The great Jesuit missionary, St Francis Xavier, while urging the casados to marry their local concubines, drew the firmest of colour lines. 'When the concubine was dark in colour and ugly featured, he employed all his eloquence to separate his host from her. He was even ready, if necessary, to find him a more suitable mate."'(Pearson, 1987:101) In all it is narrated that about 450 Portuguese were married to native women before [Albuquerque] left Goa for Malacca." (Pearson, 1987:153) But in practice his instructions were ignored after his short spell in power in the Portuguese India. As a result their children could not be distinguished on the basis of colour as they were as black as the natives. Describing the children of the Portuguese Linschoten writes: "the posteritie of the Poringales, both men and women being in the third degree, doe seeme to be naturall Indians, both in colour and fashion." (qtd in Pearson, 1987:101) In a similar vein Hamilton in his Description of Hindostan writes: "In the southern quarter (of Backergunje) there still exist several original Portuguese colonies ... . They are a meagre, puny, imbecile race, blacker than the natives, who hold them in utmost contempt, and designate them by the appellation of Caula Ferenghies, or black Europeans." (qtd in Hobson-Jobson, 1903:354) However, unlike AngloIndians Indo-Anglians are not a hotchpotch of culture in terms of their ethnicity. So we have to look for their beliefs and other issues.

Telling the characteristics of Indo-Anglians Sajith Pai writes: “... [they]

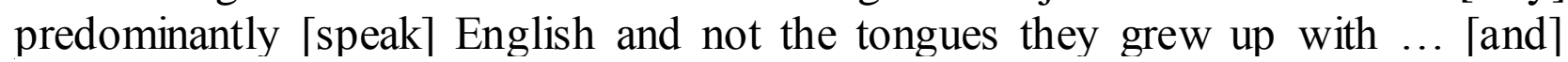
constitute an influential demographic, or rather a psychographic, in India - affluent, urban, highly educated, usually in intercaste [sic] or inter-religious unions. ... Unlike Anglo-Indians, ... Indo-Anglians comprise all religions, though Hindus dominate. ... They fall well within the top $1 \%$ of India economically ... ." (scroll.in/magazine/867130) The Anglo-Indians insist on maintaining a distinct 
identity on the basis of their language and British legacy in matters of dress, diet, literature, music, religion, culture and marriage as is evident from the following remark of Blair R. Williams who himself is an Anglo-Indian: "The Anglo-Indians did not accept their Indian heritage, tending to look down upon Indians of other communities. Their middleman role in government merely consolidated this attitude. ... And so the Community lived for over two hundred years of British rule, not being accepted by either the British or the Indian communities. Many sociologists classified them as "marginal' to the British and Indian cultures." (Williams, 2002:ix) Urban dwelling of the Anglo-Indians is one of the causes of their failing to mix-up with the rest of Indians. During freedom struggle they were by and large distrusted and treated as anti-nationals because of their West-oriented culture, their aloofness from the mainstream Indians and their siding with the British. Perhaps they could foresee that competition, and not ascription, will be the linchpin of the new nation (independent India) and they, without any British crutches, would encounter insurmountable difficulties. Therefore, after independence a large number of them chose to relocate themselves in the white skinned and Protestant-Christian dominated western countries (like Britain, Canada and United States) and eastern countries (like Australia and New Zealand) though at times they were treated as half-castes and not as equals there. Many Anglo-Indians continue to migrate from the land of their birth even today despite generous guarantees given to them by the Constitution and the government of India. However, they have created many institutions the legacy of which continues to flourish in India. Modern Indian education system is a good example of this legacy.

The institution of Anglo-Indian schools is a living a remnant of the European colonial education in India. Sudarshana Sen identifies three types of such schools that came into existence during the reign of East India Company with a view to provide the boys subordinate positions in the Company's military and civil service and prepare the girls (the first ever school for the girls of the community was started in 1856) as prospective wives. They are: charity, military and private schools (Sen, 2010) Sen holds that these schools did not come under the influence of Swadeshi movement and the Non-Cooperation movement and therefore they remained isolated from mainstream education, politics and social life and in turn were insulated against nationalist ideals. (Sen, 2010:117) The Anglo-Indians ignored Sadler Commission's recommendations (1917) that the European schools should teach principal vernaculars and should include the study of Oriental languages such as Sanskrit, Persian and Arabic in the curriculum. The Hartog Committee in 1929 again recommended that Indian languages should replace English as medium of instruction in secondary schools, vocational training should be encouraged and more diversified courses should be introduced at school level. Initially students from nonAnglo-Indian community were not admitted to these schools; it was only in 1921 that they were allowed to the limit of fifteen per in the Conference of the Heads of European Schools. Later the Government raised this limit to twenty-five per cent. Presently the number of Anglo-Indian students in these schools is relatively small, in some instances less than five per cent of the total enrolment (Gist and Wright, 
1973:116). Ann Lobo, in her well researched article in two parts, highlights that the much sought after Anglo-Indian schools work on the premise of "racial, linguistic and religious framework" and continue to "extend the power, prestige and wealth of the British government and Christian missionaries." She holds that the education in these schools promotes inequality, suppression, Christianity and subordination. According to Ann these schools create "pliant, cheap, literate and loyal workforce" (Lobo, 1996a:19) and propagate colonial legacy by placing undue emphasis on English language. (Lobo, 1996a:13-30 and Lobo, 1996b:13-34) Ann opines that "Anglo-Indian schools are the process which creates a mind set [...]." (Lobo, 1996b:13) Evelyn Abel, elaborates it as an effort "to perpetuate some form of snobbery and snobbery rather than pride in an Anglo Indian identity". (Abel 1988: 85). All those who go these schools inherit this snobbery, pride and haughtiness. The products of these schools are turned out as Indo-Anglians. Thus, there are many similarities between Anglo-Indians and Indo-Anglians. As Anglo-Indians find their affinities with the British more than the Indians the Indo-Anglians too find themselves more comfortable with the alien former colonisers. It can safely be presumed that Amanuddin does not wish to be sided with former colonisers and therefore expresses his disapproval of the label "Indo-Anglian".

\subsection{A confusion of language}

India has the unique distinction of having more than 1650 living languages and every Indian by and large is a polyglot. However, under the impending Globazilation and education in Anglo-Indian Schools English in India has emerged as a language of opportunities at the cost of sensibilities. English does not find a place in the Eighth Schedule of the Indian Constitution though its use is admissible for various purposes under Articles 210, 343(2), 345, and 348(3)(iii). English enjoys the status of official language. Studies in English Literature/Language continue to be promoted in a big way in all Indian universities and graduating in English is considered socially prestigious and valuable. Even M K Gandhi, J L Nehru and other nationalist leaders used English and published in it prolifically in the heydays of freedom movement. However, English in post-independence India has emerged as a language of fashion, aspiration and necessity for a certain class of people that Saritha Rai describes as "English Only' Generation” (nytimes.com). Sajith Pai calls this class "Indo-Anglian" and opines that they owe their existence to the "growing westernisation, demand for English education and ... intercommunity marriages" (scroll.in/magazine/867130). Language being a source of culture the adoption of a foreign language alienates a person from his roots and consequently social and emotional issues crop up. Gopika I S' report "Rise of the Indo-Anglians in Kerala" in The New Indian Express (February 16, 2018) highlights the fact that the use of English by the Indo-Anglian families in the public spaces is not appreciated by the locals. Rather it is looked at as "their inherent need to show off" even by the experts in the field though some of the families might be using it out of necessity. (newindianexpress.com) The use of the colonial masters' language subjugates a person even mentally. Keki Daruwalla has rightly remarked: "Colonial history shows that language can be as domineering as any occupational army. It supplants 
myths, whole iconographies, world-view, ideology. It ushers in its own symbols and its own values. An armada of new texts sails in. Old dogmas and bigotries are swept away and exchanged for new ones." (poetryinternationalweb.net) So, the first confusion is if a person should choose to use one's mother tongue or the coloniser's language.

Even though the first collection of poetry in English (The Sháï and Other Poems, 1830) by an Indian, Kas iprasad Ghose, was published five years earlier than Macaulay's Minutes were approved the process of creating English/alien "mind-set" was formally introduced in India with the approval of Macaulay's Minutes by the then Governor William Bentinck in 1835. Macaulay was very clear in his ideas and objectives: "We must at present do our best to form a class who may be interpreters between us and the millions whom we govern, -- a class of persons Indian in blood and colour, but English in tastes, in opinions, in morals and in intellect." (Minutes 2nd February 1835) The impact of this education was great on the psyche and mental make-up of the Indians. The architect of English Education in India, Thomas Macaulay, himself reported the impact of this education on Indians to his father Zachary Macaulay in his letter dated 12 October 1836 from Calcutta:

"Our English schools are flourishing wonderfully. ... The effect of this education on the Hindoos is prodigious. No Hindoo who has received an English education ever continues to be sincerely attached to his religion. Some continue to profess it as a matter of policy. But many profess themselves pure Deists, and some embrace Christianity. ... It is my firm belief that, if our plans of education are followed up, there will not be a single idolater among the respectable classes in Bengal thirty years hence. And this will be effected without any efforts to proselytise, without the smallest interference with religious liberty, merely by the natural operation of knowledge and reflection. I heartily rejoice in this prospect...." (Trevelyan, 1876: 454-56, emphas is added)

It is just unimaginable that English education had created this impact within eighteen months of the Minutes. Actually, forty Seminaries had been active in teaching for several years in Bengal and the people of all castes showed enthusiasm for English schools. However, in comparison, Muslim population particularly from Madras and Bombay did not show much interest because of their hostility to Macaulay's education polic ies. This laid the foundation to the start of westernisation of the Indian society. This new breed of westernised Indians looked down upon fellow Indians as inferiors, which lead to further divisions in the society. No wonder that the Indians who go to attend Anglo-Indian schools ${ }^{6}$ feel alienated in the Indian society as they try to imitate the Anglo-Indians both consciously and unconsciously in some of the above traits.

It is quite a logical fall out that those who start imitating and adopting the English language also start imitating the English life style; from writing in English, they are generally led, to convert themselves to Christianity and to settle abroad. The above mentioned facts are also corroborated by a look into the lives of the authors who started writing in English in the early phase. ${ }^{7}$ Of course, there were 
some $^{8}$ who resisted the conversion of religion ${ }^{9}$ and adoption of a new idiom and tried to stick to their faiths. That the church influenced and dented the patriotic sensibility is also clear from the following description in the encyclopaed ia: "The Christian Patriot, the church's leading Indian weekly newspaper, conceded that with a few notable exceptions Indian Christians kept away from the nationalist movement. It urged Christians to recognize they had a duty toward India and then declared that 'a real Christian cannot help being at the same time, a true Indian patriot' (cited in Houghton, p. 203). ... [Bishop Henry Whitehead of Madras] felt political agitation was contrary to the spirit of Christ." (encyclopedia.com) No wonder one finds a different kind of thematic flavour and treatment of the subject in their writings. For example, Bankim Chatterji wrote an incomplete novel Rajmohan's Wife in English. But his switching over to Bangla as a medium changed his tone and tenor from that of imitation to that of revolution in Anandamath. This change in attitude and attitude on account of the choice of language is visible even today in literature as well as journalism. Even in the contemporary times all those who write imitative poetry, copy various isms and perhaps boast upholding a Semitic religion are easily recognised by "big publishers" and brought into the canonical literature. With the globalization the process has become faster as has been indicated by Sajit Pai and others (see supra). Amanudd in has chosen to write in English which is not his mother tongue but is a language of his bread and butter. It can rightfully be concluded that his quarrel is not with the language but with the change of sensibility that it brings with it.

\subsection{A Nullity of Imagination}

Prafulla Chandra Ray, a well-known Bengali chemist, tried to oppose the education in a foreign language way back in 1932. He held that studying through a foreign language is bound to extinguish all creativity and originality. $\mathrm{He}$ comes down heavily on English medium system of education in India when he writes:

The enormous waste of time in the education of a Bengali youth is simply staggering. Six or seven years of the most precious period of a boy's career are simply wasted in learning or picking up the intricacies of a foreign tongue through the medium of which he is made to acquire knowledge. Such a monstrous and perverse arrangement does not, I believe, obtain in any other country under the sun. Education should always be imparted through the mother-tongue of the learner - the language of nursery. ... When we speak of a man being well informed we do not usually consider the medium of language through which he has picked up his knowledge. We are blindly following a pernicious system, which more than anything retards the acquisition of knowledge." (Ray, 1932: 289)

Similar sentiments have been expressed by Gandhi. By citing his own example he details how he has been a loser by using English as a medium and how a chasm between him and his family was created because of the language:

The pillory began with the fourth year. ... what I took four years to learn of

Arithmetic, Geometry, Algebra, Chemistry and Astronomy, I should have 
learnt easily in one year, if I had not to learn through English but Gujarati. My grasp of the subjects would have been easier and clearer. ... This English medium created an impassable barrier between me and the members of my family, who had not gone through English schools. My father knew nothing of what I was doing. I could not, even If I had wished it, interest my father in what I was learning. For though he had ample intelligence, he knew not a word of English. I was fast becoming a superior person. Even my dress began to undergo imperceptible changes. What happened to me was not an uncommon experience. It was common to the majority. (Gandhi, 1938)

At another place Gandhi is more explicit about the effects of English education in India:

I find daily proof of the increasing \& continuing wrong being done to the millions by our false de-Indianizing education. ... Education through the medium of a strange tongue breaks the concordance which should exist. Those who break this relationship are enemies of the people even though their motives may be honest. To be a voluntary victim of this system of education is as good as the betrayal of our duty towards our mothers. ... It has produced a gulf between the educated classes and the masses. The people look on us as beings apart from them. ... It is my considered opinion that English education in the manner it has been given has emasculated the English educated Indian, it has put a severe strain upon the Indian students' nervous energy and has made of us imitators. ... No country can become a nation by producing a race of imitators. ... The foreign medium has caused brain fag, put an undue strain upon the nerves of our children, made them crammers and imitators, unfit for original work and thought, and disabled them from filtrating their learning to the family or the masses." (www.mkgandhi.org/)

If one goes by Ray's opinion and Gandhi's experience one realizes that IndoAnglians' use of English is neither appreciated nor is desirable as it reduces their mental ability and further cuts them from their culture and their people.

James Cousins denounces the efforts of the Indian authors writing in English to be a part of English literature in very strong words (Cousins, 1918:176-77) on two counts viz. sensibility and language. Since the literature written in someone else's tongue does not reflect originality he cautions the younger writers lest they should become mere imitators: “... You will never sing your own song if you are content to echo another's: four lines struck from the vina of your own heart experience or mental illumination will be worth infinitely more to you and the world than reams of mimicry" (Cousins, 1918:156). Cousins considers literature to be a matter of sensibility and wishes the Indians to express theirs by maintaining their unique identity in their writings as well: " "Be yourselves first: do not fall under the illusory notion that you are fulfilling your ideal in desiring to write as good blank verse as Tennyson, or as fine lyrics as Swinburne." (Cousins, 1918:155-56) He cautions an aspirant Indian author over his choice of language: 
"If they must write in English, let it be in the English language only: let them keep themselves unspotted of its point of view, temperament, its mannerisms; for their repetitions of these will fail of conviction, which is one of the absolute essentials of art, since they can never disguise the fact that they are imitations, and Nature abhors imitation more that she does a vacuum: there is a chance of filling a vacuum, but none of turning an imitation into an original." (Cousins, 1918:177)

What Cousins suggests is easier said than done; rather he is envisaging a situation which has not taken shape so far as is evident from the following lament of V K Gokak about the status of Indo-Anglian writing: “... Indo-Anglian writing ... is either predominantly 'Anglian' or 'Indian'. Very rarely is a synthes is of the two perceptible in sustained works of art." (Gokak, n.d.:163) In this situation, according to Gokak, "a good deal of Indo Anglian fiction or poetry falls short of the level that our greatest writers have touched in their own languages." (Gokak, n.d.:164) Annie Montaut in her article "English in India" makes a cognitive analysis of the daily lives of the people because of the changed perception because of the foreign language. Throwing light on the issue she writes:

At the bottom of this alienation, variously described by its victims and similarly analysed, is a conflict between cognitive and perceptual patterns: the Western rational consciousness which has been inherited from the colonial past by the Indian national ideology relies on the externalization and objectification of the very notion of 'culture', whereas such an externality is totally alien to the indigenous perception. The 'Indian' feeling of belonging as an empathic relation with the moving intertwined layers of shared knowledge, beliefs and symbol, nature and culture, experienced from within and not seen as an historical legacy, experienced from the outside, has been described by many writers from as different intellectual and social stocks as A. Coomaraswamy, Nirmal Verma (2000: India and Europe), Ashis Nandy (1980: The intimate Enemy), Anantha Murthy (2008), Gandhi, as well as by foreigners such as Richard Lannoy (The Speaking Tree) or Eric Erikson (on Gandhi ).” (Montaut, 2010:19)

It is because of this changed perception of the Indo-Anglians that they are not able to appreciate the indigenous cultural and knowledge paradigms and consequently lose touch with their roots. After being uprooted from his native land India, Syed Amanuddin upon his migration to the US, like an Indo-Anglian in India, must himself be facing a crisis and conflict in his values. The issue becomes all the more complex when the writers claim that they use chaste English in their writings while Indian English is derided by using terms like Babu English, Butler English, Bearer English, Chee-Chee and Kitchen English. To rub salts to their wounds they are confronted with questions like "Is Indian verse in English only sometimes 'Indian' and only occasionally poetry?' (Naik, 1973:157) This section may be summed up by citing Salman Rushdie's opposite view. He lays blame at the door of 
Indians for not appreciating Indo-Anglian's writings and attitudes: "For some, English-language Indian writing will never be more than a post-colonial anomaly, the bastard child of the Empire, sirred on India by the departing British; its continuing use of the old colonial tongue is seen as a fatal flaw than renders it forever inauthentic. 'Indo-Anglian' literature evokes in these critics, the kind of prejudicial reaction shown by some Indians towards the country's community of 'Anglo-Indians' - that is, Eurasians." (Rushdie, 1997:xii)

\subsection{Hating Hyphens}

Barbara Godard considers the hyphen as a mark of both separation and union. (Godard, 1993: 154-55) Though A K Ramanujan had spent many years of his life in the department of south Asian languages and civilizations at the University of Chicago he "wryly described himself as "the hyphen in Indo-American studies"" (Subramaniam, 2017). The identity of a person may be described on the basis of race, religion, gender, economic status, nationality or blood relations. The question of one's identity is at the core of philosophical, sociological and anthropological and political inquiries. Identity has always occupied the centre stage in literary studies. With a lot of migration taking place because of the new explorations, new jobs, global economies and new and quicker means of transport the hyphenated identities have gained prominence. Since Amanuddin migrated to the US let us recall a bit of American history as well with reference to identity. With the discovery of America the project of American Dream also started taking shape. The new land was available to all (at least theoretically speaking) but the migrant was to forget his/her identity and had to work for American Melting Pot. The image of Melting Pot is no more representative of American dream. It has now yielded place to the image of Mosaic or salad bowl. With the emergence of this new image the discourse of hyphenated identities has also come into existence. With the advent of Postmodernism the notions of finality and ultimate truth have also been put to air. These developments have challenged the concept of self as a unique unit. With the emergence and acceptance of plurality as reality the multiple identities have come to stay. The best way to project them is through hyphenated expressions. The hyphenated expressions also convey a sense of simultaneity. However, hyphenated identities may also indicate fracas in one's personality, actions and words. After all a language functions on the principle of one sign, one signifier and one signified at a given moment.

Though the New Critics would not consider "I" in the poem to be the poet but the persona could be taken to a migrant American having multiple identities like the poet himself. Amanuddin has been a painter, playwright, novelist, critic, teacher and a poet all rolled into one. He has been a Kannadiga, Muslim, Indian, American, all in one. He knows Kannada, Urdu, Arabic and English. He is a born Muslim, brought up in Hindu environs who worked in largely a Christian country. To define such a persona in a single expression is a great challenge. Such a person has to indulge in endless negotiations between spaces, cultures and times to get an identity. Stuart Hall suggests that we should instead think of identity as a 'production' which is never complete but always in process, and always "constituted within, not outside, 
representation" (Hall, 1996:4). However, a poet looks neither for fragments nor for incomplete production but looks for a whole. Hyphens no doubt connect but they also leave gaps; hyphenated identities also have certain gaps. The anguish of the persona in hating hyphens is therefore quite justified.

The Indian mindset by and large does not appreciate "hotch-potch of bloodmixing". Amongst the Muslim society they are worried about the purity of blood so much they prefer to marry amongst the cousins (inter-marriages). Even the Hindu religious scriptures purity of blood has been hinted at. The following verses from the Bhagvadgita are being cited to illustrate the point:

adharmābhibhavāt krișhna pradușhyanti kula-striyah

strīṣhu dușh țāsu vārșhneya jāyate varṇa-sa inkarạ̣

sa ṅkaro narakāyaiva kula-ghnānā ỉ kulasya cha

patanti pitaro hy eșhāim lupta-pindododaka-kriyā ḥ

doșhair etaih kula-ghnānā ṁ varna-sa ỉkara-kārakaih

utsādyante jāti-dharmāh kula-dharmāśh cha śhāśhvatāh

(Bhagvadgita: I:41-43)

(Tr. "With the preponderance of vice, O Krishna, the women of the family become immoral; and from the immorality of women, $\mathrm{O}$ descendent of Vrishni, unwanted progeny are born. An increase in unwanted children results in hellish life both for the family and for those who destroy the family. Deprived of the sacrificial offerings, the ancestors of such corrupt families also fall. Through the evil deeds of those who destroy the family tradition and thus give rise to unwanted progeny, a variety of social and family welfare activities are ruined." (Bhagvadgita: I: 41-43 www.holy-bhagavad-gita.org/chapter/1/)

However, science values hybrids of various sorts, human beings being no exception to it because science does not follow the rules of morality. In this background Amanuddin's wish of aborting "affair between an indo and an anglo" both at physical and metaphysical levels is quite understandable.

Anthropologists, sociologists and geographers tell us that human beings have migrated from one geographical location to another and so have their ideas. The Vedic Prayer: krinvanto vishwam aryam (Rig Veda IX.63.5; Tr. "Let the entire world be cultured") and yatra vishvam bhavati ek nidam (Yajurveda, XXXII.8; Tr. "Where the world a solitary abode") indicate Indians' wish to treat the whole world as one single family. The following oft quoted Vedic idea ékam vadanty (Rig Veda I.164.46 Tr. "That which is One, the sages speak of as Multifarious") clearly indicates about the existence and acceptance of the multirealities. The natural corollary is that the proposition of hold ing only one idea to be valid and good for all and therefore making it prevail is unacceptable to an Indian. Rather, it imbibes the idea that the people at different levels of society, state, country and world may stay and live together holding different viewpoints and worldviews. Besides respecting their mutual differences they look after each other's needs and interests as in a family different members do and explore the truth. In 
the Atharva Veda (bhumi sukta), the Rishi is delighted in proclaiming himself to be the son of the mother Earth: mata bhumi putro aham prithviyah (XII.1.12). The Sukta further hails the earth for giving shelter to numerous faiths: jana vibhrati bahudha vivacasam nana dharmanam prithvi yathoksam. (XII.1.45 Tr. "The earth that holds people of manifold varied speech, of different customs, according to their habitations") Similarly, the Vedic idea of vasudhaiva kutumbakam (Tr. "The entire world constitutes a family") provides ample space not only to the human beings but also to the animals, birds, plants, minerals and other organisms in the ecosystem as it is enshrined in the idea that everything is just the manifestation of God and has one pervading soul (atma). As in a unit family everything and everybody becomes a part of the family similarly in this world everything and everybody belongs to one family. The entire śloka containing this wish condemns all sorts of discrimination. It reads: ayam் bandhurayaìn nēti gaṇanā laghucētasām|udāracaritānām tu vasudhaiva kuțumbakam \|71\| (Maha Upanishad VI.71) (Tr. "Discrimination saying 'this one is a relative; this other one is a stranger' is for the mean-minded. For those who're known as magnanimous, the entire world constitutes but a family.") This idea cuts across time and geographical location as is evident from the Panchatantra, the Hitopadesha and the Tamil Sangam literature. The idea is not just about peace and harmony among the societies in the world, but also about a truth that somehow the whole world has to live together like a family. This is the reason why Hindus think that any power in the world, big or small cannot have its own way, disregarding others. Amanuddin echoes Indian concept of globalization and rightfully condemns "the artificial bridges" and "artificial values" in the name of race, religion and language, "hyphenated minds" and prejudiced offsprings of "unenlightened souls".

\section{Notes}

1. It reads as: "Indo-Anglian a., of or pertaining to literature in English written by Indian authors; also as sb., a writer of such literature; ... 1883 in K. R. Srinivasa Iyengar Indian Writing in English (1962) i. 3 *Indo-Anglian, 1935 A. R. Chida (title) Anthology of Indo-Anglian Verse. 1943 K. R. Srinivasa Iyengar (title) Indo-Anglian Literature. 1962 Times Lit. Suppl. 10 Aug. 596/3 Authors such as R. K. Narayan, Dom Moraes, Balachandra Rajan (now called 'Indo-Anglians') find their public in the West, rather than inside India itself. 1969 Sunday Standard (Bombay) 3 Aug. (Mag. Sect.) p. vii/7 Anita Desai is one of the most competent amongst the small band of Indo-Anglian novelists who have successfully established that a branch of English literature can grow and flourish as well in India as .. [sic] in Australia or Canada." (1991:882-83)

2. The entry on the term in The New Shorter Oxford English Dictionary on Historical Principles (Vol. I) reads as: "Indo-Anglian a. \& n. (a) adj. of or pertaining to literature in English written by Indian authors; (b) n. a writer of such literature: L19." (1993:1353)

3. Syed Amanudd in was a versatile writer who had written poetry books like The Forbidden Fruit (1967), Tiffin State Hospital (1970), Shoes of Tradition (1970), The Children of Hiroshima (1970), Poems of Protest (1972), Lighting and Love (1973), The Age of Female Eunuchs (1974), Adventures of Atman (1977), Gems and Germs (1978), Make me your Dream (1982), Poems (1984) and Challenger Poems (1988), plays like: System Shaker: Plays (1972) and The King Who Sold His Wife (1978), a novel Passage to the Himalayas (1979), and the critical 
works like Hart Crane's Mystical Quest and Other Essays (1967) and World Poetry in English: Essays and Interviews (1981). He was also the founder and editor of two literary magazines: Poetry East west (1967-1972) and Creative Moment (1972). His poems have been widely translated into French, Urdu, and Kannada.

4. The entire poem as finds in an anthology is as follows:

no i don't want to be

a hotchpotch of culture

a confusion of language

a nullity of imagination

an abortive affair between an indo $\mathrm{n}$ an anglo

i hate hyphens

the artificial brid ges

between artificial values

in the name of race religion $\mathrm{n}$ language

i damn all hyphenated minds

prejudiced offsprings of unenlightened souls

i denounce all labels and labelmakers

$i$ refuse to be a moonrock specimen

to be analyzed labelled $\mathrm{n}$ stored

for a curious gloomy fellow to

reanalyze reclassify me

for shelving me again

they call me indo-anglian

i don't know what they mean

cauvery flows in my veins

chamundi hills rise in my mind with stars afloat

eyes of the goddess smiling on the slain demon

brindavan fountains sing in my soul their musical colours

but $i$ am not tied down to my childhood scene.

$i$ have led languages by their ears

$i$ have twisted creeds to force the truth out

$i$ have burned candles in the caves of prejudice

$i$ have surged in the oceans of being

$i$ have flown across the universe on the wings of my thought

they call me indo-anglian

the mistaken misinformed folk

$\mathrm{n}$ class me with a small group of writers

cloistering me

crippling me

i would rather roam with kalidasa $n$ kabir

or go on a spiritual journey with dante

meditate with khayyam on the mathematics of existence

or sing with ghalib the anguish of love

or drown with li po kissing the moon's reflection in the river

they call me indo-anglian

it's true i write in english 
dream in the language of shakespeare $n$ keats

but $i$ am not an anglo my friend

i am a poet

$i$ have lived forty centuries under various names

i am now amanuddin

(Amanuddin, Syed. (2008). "Don't Call Me Indo-Anglian," In An Anthology of Commonwealth Poetry. C. D. Narasimhaiah (ed.), New Delhi: Trinity, 2016. Print.)

Note 5: Anglo-Indian schools have a protection under Indian Constitution (Article 29(1), Article 30(1), Article 337 (irrelevant today as the time limit mentioned in it is long past) and Article 366(2) though confusion prevails over their status as it is not clear if they are the institutions run by linguistic or religious minorities.

Note 6: Most of these schools are "founded on the Biblical principle that 'the fear of the lord is the beginning of wisdom"" and are run on the patronage of parents, old students, well-wishers and the church congregation" (Chitra, Rachel. (November 20, 2017) "Reminder of Anglo-Indian Past, School Stands Tall at 175 Years" https://blogs.timesofindia.indiatimes.com/trackingindian-communities/reminder-of-anglo-ind ian-past-school-stands-tall-at-175-years/)

Note 7: For example, Dean Mahomed, the first Indian to publish a book in English, was baptised in the Roman Catholic church of St. Finbarr's, Cork, in 1791. The religious reformer and playwright Krishna Mohan Banerjee (The Persecuted: or, Dramatic Scenes Illustrative of the Present State of Hindoo Society in Calcutta, 1831) converted to Christianity in 1832. Rammohun Roy started as a reformer of the prevailing Brahmanism of the time (by founding Atmiya Samaj in 1815 and Brahmo Samaj under the influence of Christianity at Calcutta in 1828) but ended up as a Christian in Arnos Vale Cemetery in Bristol. Michael Madhusudan Dutt embraced Christianity in spite of the objections of his parents and relatives on 9 February 1843. Dutt family (Govind Chunder Dutt and his siblings Romesh Chunder Dutt, Aru Dutt and Toru Dutt) embraced Christianity in 1862. Bhavani Charan Bandyopadhyay renamed himself Brahmabandhav Upadhyay after his conversion to Christianity in February 1891.

Note 8: Like Bankim Chandra Chatterji, Sri Aurobindo, Manmohan Ghose, M K Gandhi, Rabindranath Tagore, Sarojini Naidu and Harindranath Chattopadhyay

Note 9: The process of religious conversion is still on as is clear from the list of notable converts to Christianity from Hinduism (https://en.wikipedia.org/wiki/List_of_converts_to_ Christianity_from_Hinduism)

\section{References}

Abel, E. (1988). The Anglo-Indian Community: Survival in India. Delhi: Chanakya.

Atharva Veda. Retrieved from: http://vedpuran. files.wordpress.com/2011/10/atharva-2.pdf

Bethencourt, F. (2013). Racisms: From the Crusades to the Twentieth Century. Princeton: Princeton UP.

Bhagvadgita:The Song of God. Retrieved from: www.holy-bhagavad-gita.org

Constitution of India [The]. (2007). New Delhi: Ministry of Law and Justice, Govt of India, 2007, Retrieved from: www.lawmin.nic.in/coi/coiason29july08.pdf.

Cousins, J. H. 191 The Renaissance in India. Madras: Madras: Ganesh \& Co., n. d., Preface is dated June 1918, Retrieved from: https://archive.org/details/in.ernet.dli.2015.203914

Daruwalla, K. (2004). The Decolonised Muse: A Personal Statement. Retrieved from: https://www.poetryinternationalweb.net/pi/site/cou_article/item/2693/The-DecolonisedMuse/en

Gale, T. (n.d.) Christian Impact on India, History of. Encyclopedia of India. Encyclopedia.com. Retrieved from: https://www.encyclopedia.com. 
Gandhi M K. (1938). My Own Experience. Harijan, Retrieved from: www.mkgandhi.org/ indiadreams/chap44.htm

---. "Medium of Education". The Selected Works of Gandhi, Vol. 5, Retrieved from: www.mkgandhi.org/edugandhi/education.htm

Gist, N. P., Wright, R. D. (1973). Marginality and Identity: Anglo-Indians as a Racially-Mixed Minority in India. Leiden: Brill.

Godard, B. (1993). Marlene NourbeSe Philip's Hyphenated Tongue or, Writing the Caribbean Demotic between Africa and Arctic. In Major Minorities: English Literatures in Transit, (pp. 151-175) Raoul Granquist (ed). Amsterdam, Rodopi.

Gokak, V K. (n.d.). English in India: Its Present and Future. Bombay et al: Asia Publishing House. Retrieved from https://archive.org/details/in.ernet.dli.2015.460832.

Gopika, I S. (2018). Rise of the Indo-Anglians in Kerala. The New Indian Express. Retrieved from www.newindianexpress.com/cities/kochi/2018/feb/16/rise-of-the-indo-anglians-in-kerala1774446.html

Hall, S. (1996). Who Needs 'Identity'? In Questions of Cultural Identity, (pp. 1-17). Stuart Hall and Paul du Gay (eds.). London: Sage.

Lobo, A. (1996a). Anglo-Indian Schools and Anglo-Indian Educational Disadvantage. Part 1. International Journal of Anglo-Indian Studies, 1(1), 13-30. Retrieved from www.international-journal-of-anglo-indian-studies.org

---. (1996b). Anglo-Indian Schools and Anglo-Indian Educational Disadvantage. Part 2. International Journal of Anglo-Indian Studies. 1(2), 13-34. Retrieved from: www.international-journal-of-anglo-indian-studies.org

Maha Upanishad. Retrieved from: http://www.gayathrimanthra.com/contents/documents/ Vedicrelated/Maha_Upanishad

Montaut, A. (2010). English in India. In Problematizing Language Studies, Cultural, Theoretical and Applied Perspectives: Essays in Honour of Rama Kant Agnihotri. (pp. 83-116.) S. I. Hasnain and S. Chaudhary (eds). Delhi: Akar Books. Retrieved from: https://halshs. archives-ouvertes. fr/halshs-00549309/document

Naik, M K. (1973). Indian Poetry in English. Indian Literature. 16(3/4) 157-164. Retrieved from: www.jstor.org/stable/24157227

Pai, S. (2018). Indo-Anglians: The newest and fastest-growing caste in India. Retrieved from: https://scroll.in/magazine/867130/indo-anglians-the- newest-and-fastest-growing-caste-inindia

Pearson, M. N. (1987). The Portuguese in India. Cambridge: Cambridge UP.

Rai, S. (2012). India's New 'English Only' Generation. Retrieved from: https://india.blogs.nytimes.com/2012/06/01/ind ias-new-english-only-generation/

Ray, P. C. (1932). Life and Experiences of a Bengali Chemist. Calcutta: Chuckervertty, Chatterjee \& London: Kegan Paul, Trench, Trubner. Retrieved from: https://archive.org/details/ in.ernet.dli.2015.90919

Rig Veda. Retrieved from: http://www.sanskritweb.net/rigveda/rv09-044.pdf.

Rocha, E. (2010). Racism in Novels: A Comparative Study of Brazilian and South American Cultural History. Newcastle upon Tyne: Cambridge Scholars Publishing.

Rushdie, S., West, E. (Eds.) (1997). The Vintage Book of Indian Writing 1947 - 1997. London: Vintage.

Sen, S. (2010). Education of the Anglo-Indian Community. Gender and Generation: A Study on the Pattern of Responses of Two Generations of Anglo-Indian Women Living During and After 1970s in Kolkata, Unpublished Ph D dissertation. Kolkata: Jadavpur University. Retrieved from: http://shodhganga.inflibnet.ac.in/bitstream/10603/176756/8/08_chapter\% 203.pdf 
Stephens, H. M. (1897). The Rulers of India, Albuqurque. Ed. William Wilson Hunter. Oxford: Clarendon Press. Retrieved from https://archive.org/details/in.ernet.dli.2015.156532

Subramaniam, A. (2017). Speaking of Ramanujan. Retrieved from: https://indianexpress.com/ article/lifestyle/books/speaking-of-ramanujan-guillermo-rodriguez-when-mirrors-arewindows-4772031/

Trevelyan, G. O. (1876). The Life and Letters of Lord Macaulay. London: Longmans, Geeen, \& Co. Retrieved from: https://archive.org/details/lifelettersoflor01 tre vuoft

Williams, B. R. (2002). Anglo-Indians: Vanishing Remnants of a Bygone Era: Anglo-Indians in India, North America and the UK in 2000. Calcutta: Tiljallah Relief.

Yajurveda. Retrieved from: http://vedpuran.files. wordpress.com/2011/10/yajurved.pdf

Yule, H., Burnell A. C. (1903). Hobson-Jobson: A Glossary of Colloquial Anglo-Indian Words and Phrases, and of Kindred Terms, Etymological, Historical, Geographical and Discursive. Ed. William Crooke. London: J. Murray. Retrieved from: https://archive.org/ details/hobsonjobsonag100croogoog 